\title{
Nadayoga and the Seven Steps to Liberation: A Reading of Vemana and Tyagaraja
}

\author{
P. Mallikarjuna Rao \\ Kakatiya University
}

\begin{abstract}
Naadamu nerigina yogiyu
Modambuna jivunerigi muktiki danou

Naadamu muktipradamani

Saadarumuna janulakella chaatara Vema
\end{abstract}

(Brown, 2001)

"The yogi who knows Naada will know with joy the jiva within. So, Vema proclaim to the world that Nada is a means to attain liberation".

This verse by the early eighteenth century Telugu saint poet Vemana refers to one of the most ancient spiritual practices. The poet says that by merging one's self into the primeval sound Om which arises from the heart centre, a yogi attains mukti; that is the release from the cycle of birth and death. Saints like Tyagaraja and others to achieve this exalted goal adopted music as a means because true music emanates and dissolves into Om and the ultimate goal of all music according to Bharatiya tradition is God-realization, in other words self-realization.

The basic theme of the Bharatiya culture has never been merely the achievement of material glory however great it was, for the great sages have realized the temporality of material achievements as well as life, which too is materialistic and transient. Life by itself is materialistic, but it is by the ceaseless pursuit of the Ultimate that it is transformed into spiritual. As such the Baratiyas treated life as a sojourn on the earth and tried to discover its purpose and meaning. They considered life, until one attained mukti as a journey that has a starting point and a destination. In a larger perspective, each life for soul is a sojourn on the path of "point of no return". So, each life makes sense when one discovers its theme and scheme. "The theme unfolds through a plot and each plot has an ending and marks a stage in this pursuit, the seeker adopts different paths and bhakti is one such" (SSS Murty, 1977).

Geeta gaseema yogasyat

Yogaadeva Sivaikyata

Geetagnow yadi yogena

Sayati Parameswaram.

(Sootha Sambita)

"By practicing the great yoga of music, a man is able to merge in Paramasiva. With the help of yoga of musical knowledge (Nada Yoga), a man is being redeemed." 
Yogis like Vemana practiced Hathayoga, which consists of two "Upa Yogas" (supplementary yogas); they are Mantra yoga and Laya yoga. Laya yoga is also known as Nada yoga as it deals with sound. While in the former the Sadhaka (practitioner) practices the chanting of a mantra both outwardly and inwardly, so deeply and so intensely that he/she gets absorbed in it, in the latter the body and soul are cleansed by Pranayama (breath-control) and meditation (dhyana) respectively, and the nada, the sound is constantly heard from inside. (RA Sarma, 2010)

A yanahatanada mentayu nudbhutambayi yaatmalo

Mroyuchundu nirantarambu samudraghoshamubhangi bhrum

Gayatatdhvani riti, venusamanchita swaralila, vee

Nayatambagu mrota chandmunan manolayahetuvai.

(Sivayoga: 3)

"The 'anahata' nada, which keeps ringing in the heart ceaselessly like the tumult of the sea, like the drone of the bee, like the melodious notes of the flute, like the magical notes of the lute, remains as the cause of the mind's dissolution or merger with the Ultimate."

In the Bharateeya tradition, many of the bhaktas pressed music into service to achieve their spiritual goal. The names which immediately come to our mind in this context are Tyagaraja, Annamacharya, Purandara and a host of others from the South, Meera, Surdas and many others from the North.

Lord Krishna who is described as "Yogeeswara", that is the lord of the Yogis, proclaims in the Gita that He is the Samaveda among the Vedas, Indra among the Devas, mind among the senses, and also the power that pervades the elements"(1 $0: 22)$. The origin of Indian music is generally traced to the Sama Veda. So the lord proclaims in the Gita that he is the Sama Veda among the Vedas. He also declares that He is the Pranava, Om that pervades all the Vedas (7:8). The Lord claims that He is the Nadaswaroopa, the personification of the Nada. As such the upaasana of the nada is His upaasana and merger into Om is a merger into Him that is mukti. Hence yogi Vemana says that nadopasana is a path to mukti.

Nada yoga is a discipline of sound which leads one to Nada Brhaman, the eternal, Supreme Consciousness, a luminous, pure vibration. To quote Vemana again:

Nadabinduvulanu nadambugajesi

Nadabindu kalala nadambuganu

Jesi nadamarachi chintimpa yogambu

(Brown, 2001)

"Coverting the nada and the bindu into a single nada and again blending nada, bindu and kala into a single nada and thereby paying it attention with the utmost concentration is the true yoga" (Tr. Mine). WJ Jackson offers an interesting interpretation of this verse. He observes: "Vemana described the cosmological evolution of the gross from the subtle in a specific series of changes. First light, then cosmic sound, then atoms (or 'atomic soup' as some call it) then heaven and earth. "The primal vibration (nadam) emanates from the light (jyoti), the fine particles (bindu) emerge from the nadam; and from the primordial particles earth and heaven are born" (256). He finds this parallel between modern science and Hindu intuition very remarkable.

Converting nada into bindu is to seek the source of the nada, that is bindu which according to Hindu scriptures is situated in the heart centre, the spiritual heart which is on the right side. Nada is only a path, the pursuit of which helps one merge into the bindu. To convert kala and bindu into a single nada is to retain one's self, which is conative even while it is lost into the bindu. This, in other 
8 | Nadayoga and the Seven Steps to Liberation: A Reading of Vemana and Tyagaraja

words, is Sahaja Samadhi. This is a mystical phenomenon to which any explanation is a poor substitute. The above experience, which can be described as Nada Yoga, leads one to Nada Brahman, consciousness, which is transcendental, eternal, pure, and luminous. The yogi by meditating on Omkara arising from the Anahata Chakra meditates on it as we can see in the verse from Vemana.

Mundakopanishad states thus: Om is the bow. The Atman inside is the arrow and the Brahman is the target. With unswerving mind if one concentrates on the target and hits, like the arrow in the target one becomes part of the Brahman" (II: 4) These lines from the Upanishad clearly point out that with $\mathrm{Om}$ as an instrument one can reach the Brahman. The Maandukyopanishad speaks about the all-pervasive, transcendental nature of Nada that is Omkara: "The phenomenal world is Omkara. Whatever existed in the past or present or exists in future is also Omkara" (I: 1)

It is in this context what Krishna said in the Gita assumes greater significance. The Sama Veda renders the Rigvedic mantras musically thereby emphasizing the role played by the allpervasive Nada. By chanting the Sama Vedic Mantras one is not only able to visualize the devas described in the mantras, but also establish a mystical harmony with the all-pervasive Nada. This quintessentially is Nada Yoga and it helps one transcend the individual to merge in the Universal. When Krishna says that He is Sama Veda perhaps what He means is that He is a yogi and that He is all-pervasive. But some commentators opine that since He loves music or belongs to Sama Veda Sakha (Samaveda sect), He has called Himself Sama Veda among the Vedas. In the Vishnu Purana it is said, "All songs are a part of Him who wears the form of sound." Sarangadeva's treatise on music Sangeeta Ratnakara (13 ${ }^{\text {th }}$ century) suggests that the worship of Nada Brahman is a way to liberation: "We worship the Nada Brahman (Divine sound), the life all beings, transformed in the shape of the world, the sentience, the bliss". (Jackson, 1993) A shloka from the legendary Swararnava (an Ocean of musical notes) describes the divine nature of music thus: "In the centre of the body is the prana; in the centre of the prana is dhvani; in the centre of dhvani is nada; in the centre of nada is Sadasiva, the Supreme Lord" (Jackson, 1993).

The practice of Nada Yoga is very complex and calls for a rigorous spiritual practice. Its origin can be traced back to the Vedas. Chanting of Vedic mantras with proper stress and intonation was greatly emphasized. Even to this day this holy and hoary tradition is kept alive. It is believed that without the correct chanting of the mantra it would not yield any result. The significance of the Bijaksharas (seed sounds) can be appreciated fully if we understand this fact. The musical sound or nada is the form and at its centre we have the Supreme godhead, Sadasiva. "Only by sound is the non-sound [that which transcends sound] revealed" (Maitri Upanishad) (Jackson, 1993).).

The great Sanskrit poet Kalidasa with a slight modification embodied this profound concept in his famous invocatory shloka to his kavya, Kumarasambhavam.

Vaagrtha viva sampruktou Vagartha pratipatteye

Jagatahpitarou vande Parvatiparameswarou.

In this shloka, Kalidasa describes the goddess mother Parvati (prkriti) as the form and Siva as the meaning. While Vak, the sound or Nada is manifest, Siva, the Brahman is the unmanifest and Siva is revealed through Parvati. A sound manifests in the form of vibration and vibration is the quality or characteristic of Akasa or ethereal space. "The Anahata sabda is eternal and all pervasive, mysterious ringing of infinite space, from which secondary transitory sounds come into being. Everything in existence has its own share of imperishable sabda, which is the subtle aspect of its vital principle or life energy" (Jackson, 1993). That is why letters in the Alphabet in Indian languages are called 
Aksharas (imperishables). Nada has no death and it exists in all times, the past, present and the future; the Aksharas or sounds are part of nada and they are its manifestations.

When we think of yogis who have adopted the path of music, Nadopasana or Nadayoga to attain liberation, the one who comes to our mind immediately is Tyagaraja, the South Indian composer saint. Jackson says that knowledge of music and devotion to Tyagaraja is sine qua non to liberation (122): "Is there liberation on earth for those who are not enlightened, nor having true bhakti, nor the musical wisdom? (Mokshamu galadaa bhuvilo jivanmuktulu kaanivaralaku sakshtkara nee sadbhakti sangeetajnana viheenulaku?)." Further, for Tyagaraja "one who fails to swim in this sea 'which is called musical wisdom' leads a useless life and wastes his human birth, becoming 'a mere burden to the earth' (127). (Aanandasaagara meedani dehamu bhubharame Rama..)

Taking ,perhaps, cue from Krishna's proclamation in the Gita that He is the nada Om pervading all the Vedas, Tyagaraja describes Rama as the personification of nada in his keertan Nadasudharasambilan. He avers that Rama is the personification of Nada Brhaman, whom the Vedas eulogize. His bow bells are Sapthaswaras (seven musical notes) etc. He describes the person of Rama in terms of music and thereby suggests that the practice of music is the worship of Rama. This reminds one of the elaborate description of the all-pervasive nature of Purusha in Prushasooktam.

In another keertan , Nadatanu manisam, he depicts Siva as the personification of nada. He says, "To Him whose body is sound...I bow again and again...to the essence of Sama Veda..." In the same keertan he suggests that one can attain immortality by doing Nadopasana. The nada he refers to here is the essence of Samaveda (Samaveda saram), the pure nada whose transformations are described in the Samaveda. By saying that the sapta swaras have come from the five faces of Parama Siva, namely: Sadyojata, Aghora, Esana, Tatpurusha and Vamadeva, he establishes the divine origin of nada. This nada is the manifestation of Nature. Siva, who is pure and pristine consciousness, manifests in eight forms known as Ashta Prakritis or Ashta Murthis. These eight prakritis constitute His body. Of the eight prakritis one is Purusha that is Jiva; the Shastras aver that the rest seven (five elements and the Sun and the Moon) assume the form of seven swaras: Sa, Ri, $\mathrm{Ga}, \mathrm{Ma}, \mathrm{Pa}, \mathrm{Da}, \mathrm{Ni}$, and the Jivatattva is "the unstruck cosmic sound-Anahata Nada-the eternal substratum" (Jackson:, 1993).

In the keertan Ragasudharasa he is more explicit about the power of Nada Yoga. One who practices this yoga and Ragopasana will enjoy the fruits of "yagna and yoga" and become liberated through identification with Sadasiva, the all-pervasive tattva (consciousness). In another keertan "Shobhille saptaswaralu", he further dialates upon the Nadopasana. He urges his manas (mind) to worship the seven swaras as seven beautiful beings residing in the naval, heart, throat, nose and also obtaining as the essence of Gaytri Mantra which embodies the quintessence of the four Vedas. That is why Gayatri is revered as the mother of the four Vedas (Veda Mata). By identifying the seven notes , Tyagaraja projects the yogic dimension of music practice. While navel represents Manipuraka, heart represents Anahata, throat, Visuddha, nose, Ajna chakra. The essence of Veda is nada as such these notes are like seven steps to reach the primordial Om. These notes are also like seven colours of the Rainbow (black, tawny, golden, white, yellow, purple and green) when merged become one white ray. The Anahata Nada, the pure and pristine sound, emerges from the Anahata Chakra i.e. Akasa and then manifests as different sounds.
Brahmagrandhija marutanugatina
Chittenhritvamkadi
Sureenamanuranjakah srutipadam
Yoyam swayamrajate 
10 | Nadayoga and the Seven Steps to Liberation: A Reading of Vemana and Tyagaraja

Yasmatgrama vibhaga

Varnarachanalankara jaatikramo

Vande nadatanum tamuddhara

Jagat geetam mude sankaram

(Sangeeta Ratnakaram)

When Prana combines with Agni in Brahmagrandhi lying in the Mooladhara Chakra, Nada emanates and travels through navel, heart, throat, nose, and head and eventually manifests as seven swaras, seven swarasthanas, twenty two Srutis, and three Sthayees. Thus Nada manifests as self-luminous, melodious music.

Tyagaraja who was aware of this Nada makes a mention of it in his keertans. In the keertan Swararagsudha, he asserts that knowledge of music when coupled with bhakti will lead one to liberation (Swararagasudha rasayuta bhaktil swargapavargamura o manasa!). Knowing the musical sound born from the Muladhara is ecstatic liberation (Muladhara janadamerugute mudamagu mokshamura). The first aphorism in Patanjali's Yogasutras is "Yogah chittavritti nirodhah". Yoga is controlling of the mind. A tumultuous mind can never behold the Truth. So Tyagaraja says that to recognize various centres of consciousness that is Chakras, by steering clear of the tumult of thoughts is Moksha i.e. liberation. "The higher harmony inherent in the microcosm, which the person is, can be drowned out by the uproar of the physical world clamouring for attention. To overcome the mere anarchy of noise and find the perfect and eternal order in chaos is the creative bhakta's mystical task (Jackson, 1993)".

In some keertans, Tyagaraja is not as explicit about the yogic practice as for instance in "Nagu mоти..". In this popular keertan the saint-composer expresses his intense anguish at not being able to see the glowing visage of Rama. When we attempt to understand and appreciate the meaning of the keertan against the background of his yogic practice, the images therein assume symbolic significance. In his other keertans he has already described Rama as Parabrahman. To have glimpse of His beatific smile is to have the darshan of the Self. But it is elusive and not so easy to achieve. The great distance between the earth and the sky that he refers to in the keertan is the great distance between the Muladhara (Bhootatva i.e. the terrestrial consciousness) and the Anahata (Anahata i.e. ethereal consciousness). The two wings of the celestial eagle Garuda, represent the two nadis, namely Ida and Pingala. With the help of these two nadis Chicchakti, that is the Kundalini Shakti in the Sushumna nadi raises from Muladhara to Anahata. So, he fervently pleads with his lord to be benign to him and give him the darshan he has been longing for years.

Thus, Tyagaraja and saint-composers like him have used music as a powerful aid in their spiritual pursuit. If music were treated only as a means of entertainment which would ensure their material prosperity, probably he would not have declined to sing in the courts of Sarbhoji and Swathi Thirunal and enjoyed their royal patronage. His gnawing poverty failed to break his spirit and commitment to music which he held as a very sacred path. He found the seven notes of music as the seven steps to climb up the spiritual ladder to attain liberation. 


\section{References:}

Brown, CP. Tr.\&Ed. (2001) Verses of Vemana: Vemana Jnanamarga Padyalu... New Delhi :Asian Educational Services.

Jackson, William J. (1993). Tyagaraja: Life and Lyrics: Madras; OUP.

Sarma, Rallapalli Anathakrishna. (2010). Vemana: Hyderabad; Vemana Foundation.

Sastry, Kalluri Veerabhadra. (1978). Tyagaraja Keertanalu: Visesha Vivaranam, Vols. 1\&2: Madras; Swarajya Press.

Sathguru Sri Sivananda Murty's Talk after Padma Talwalkar's Vocal Concert. (1977, 21 st December). Warangal.

Dr. P.Mallikarjuna Rao retired as the Professor of English from the Kakatiya University in 2011. He did his MA in English Literature from Osmania University and MPhil and PhD from Kakatiya University, Warangal. He has more than 40 years of Teaching and Research Experience. He has taught at the Kakatiya University, Warangal, Telangana State from 1981 to 2011, Regional Institute of English, Bengaluru from 1988 to 1990. He offered courses on Bhakti Literature and Indian Writing in English for three semesters to the post-graduate students of the Hyderabad Central University from 2012 to 2013. He taught a course on Indian Writing in English at the Secunderabad P. G. College of Osmania University as a UGC Visiting Fellow in 2013. He gave lectures as a Resource Person for the UGC Refresh Course for College teachers at EFLU, Hyderabad, Pondicherry Central University, Pondicherry, Osmania University, Hyderabad, Andhra University, Visakhapatnam, Nagarjuna University, Guntur in Andhra Pradesh and Amaravati University, Maharashtra. He had also served on the PG Board of Studies of many of these Universities.

He served the Kakatiya University in many capacities; first as the Head of the English Department and later as Chairman BOS English and Dean, Faculty of Arts. He also contributed to the growth of the University by serving first as the Principal of the University PG College, Subedari and later the prestigious University Arts and Science College which has produced as illustrious personalities as Late PV Narasimha Rao, former Prime Minister of India and Prof. K. Jayashankar.

He has guided many $\mathrm{PhDs}$ and MPhils and published many research articles on various subjects as wide as American literature, African literature, Canadian literature, and Indian literature, including Bhakti literature, in India and abroad. Besides editing Critical anthologies on Post-colonial literatures (Atlantic: 2003) and Indian Writing in English (Atlantic: 1999), he has also edited English text books for degree students of the SDLCE, Kakatiya University. He has prepared Radio lessons for AIR, Bengaluru and other study materials for course participants of NCERT. He took part in many national and International seminars as a paper presenter and chaired many sessions.

In addition to these he wrote articles and gave talks on Sri Aurobindo, Swamy Vivekananda, Bhagawan Ramana Maharshi, Jiddu Krishna Murthy and the Buddha in AIR, Warangal. He is currently interested Buddhism and the spread of Dhamma. As a part of this he had a stone idol of the Buddha installed in front of the Kakatiya University Library and gave occasional talks at the Ananda Buddha Vihara, Secunderabad, now being managed by the Maha Bodhi Society of Bengaluru. 